\title{
Historein
}

Vol 7 (2007)

History and Utopia

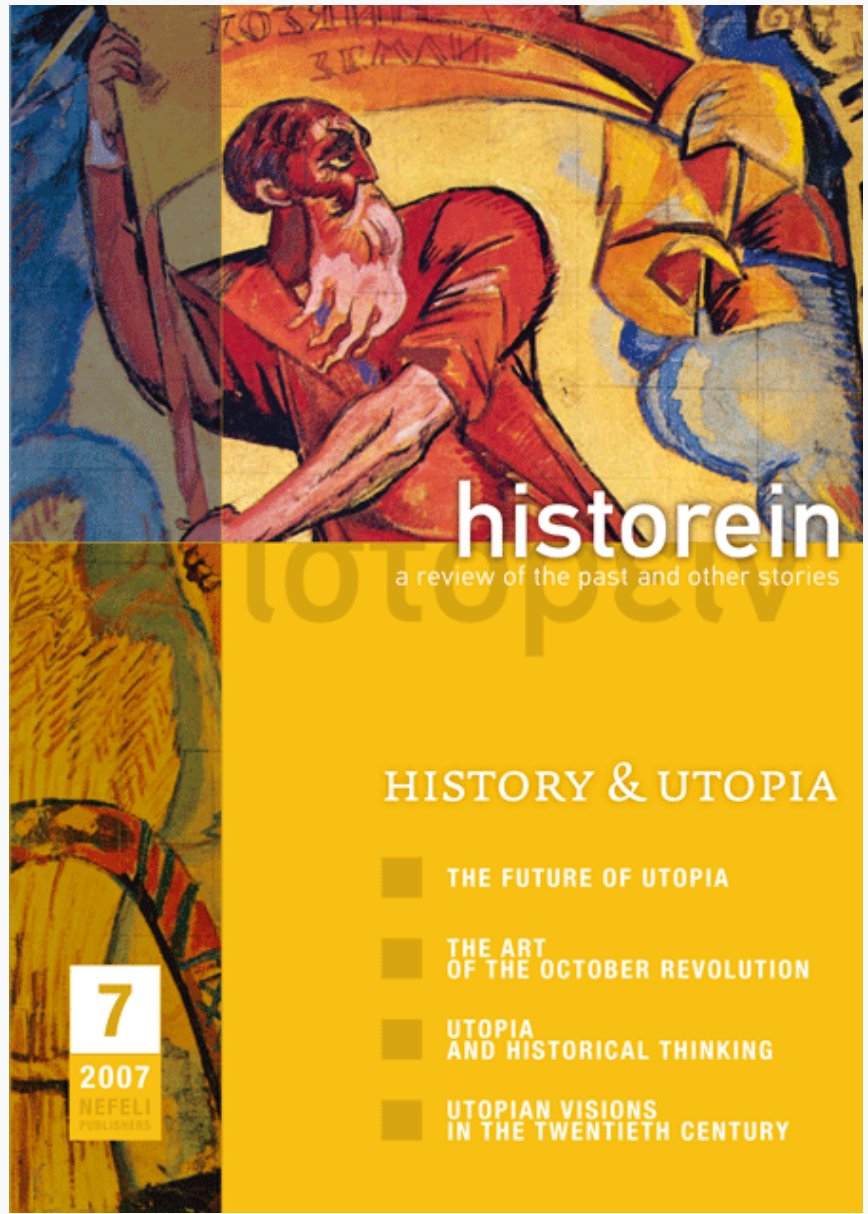

\section{History and Utopia}

Jörn Rüsen

doi: $10.12681 /$ historein.47

Copyright @ 2012, Jörn Rüsen

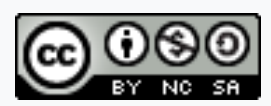

This work is licensed under a Creative Commons Attribution-NonCommercialShareAlike 4.0.

\section{To cite this article:}

Rüsen, J. (2008). History and Utopia. Historein, 7, 5-10. https://doi.org/10.12681/historein.47 


\section{History and Utopia}

At first glance, the relationship between history and utopia seems clear; they follow two different logics of sense generation which exclude each other. History is related to experience and reconstructs the temporal chain of events and their structural conditions that have led to the circumstances of present-day human life. Utopia principally transcends these circumstances, creating an image of a different world by presenting essentially a contrasting counter-concept of what actually is the case. It goes beyond all experience. History wishes to establish "how it actually was" (wie es eigentlich gewesen); " utopia is interested in showing how it actually should or could be.

However, the initial perception that this represents a contradiction is superficial. It overlooks an interrelationship between both modes of looking at the human world. Both play a role and have a place in the general framework ofculture by which practical human life is interpreted by those

\section{Introduction} who have to live it and come to terms with their lives. Hayden White has made it clear in his paper, which I will refer to later: history is the 'other' of utopia and vice versa. One cannot think of one without at least indirectly referring to the other. Both deal with change, both refer to experience and to expectation, both have an orientation function for humankind, but they do it in a completely different way, and it is this difference that gives them their peculiarity. Looking closer at this difference, one will see intermediating relationships, hidden references and dependencies.

The current discussion on utopia is characterised by a general criticism of utopian thinking which came about as a result of the fundamental change in world politics for which 1989 is a generally accepted indication. This change has been characterised as a definite end of utopian thinking - at least in the form in which it had influenced Western history, from its 
very beginning with Thomas More's famous text. ${ }^{2}$ So is utopia dead and history still alive? The articles in this volume show that this is definitely not the case; ${ }^{3}$ on the contrary: one of the most interesting points raised in different contributions is the thesis that we live in a time in which an essentially new way of utopian thinking has started. This novelty is not without consequences for historical thinking. In the mutual otherness of history and utopia, history could have changed or is changing, possibly without sufficient awareness on the part of professional historians.

I have to introduce six contributions with very different outlooks on the theme: three case studies (by Antoon de Baets, Yannis Smarnakis and Sygaro Tsiara), an overview of the twentieth century (by loanna Laliotou), a systematic analysis with a strong reference to a diagnosis of our time (by Hayden White), and one taking a general historical perspective which includes pre-modern eschatology, modern utopia and the present-day situation (by Antonis Liakos). As the volume covers a vast field, attempting to provide even a rough map of it leads to intellectual desperation. Nevertheless, the volume has its limits: all articles refer to Western history, which means that it is fundamentally lacking in an intercultural perspective, which is one of the most urgent requirements in doing history and reflecting on its relationship to other modes of cultural sense generation.

I would like to start with Hayden White's paper on "The Future of Utopia in History", which picks up the traditional difference between history and utopia, ascribing to historical thinking the reality principle of modern societies. History for Hayden White is not only represented by historical studies, but by the whole mode of historical thinking in modern times, including philosophy of history and all historical approaches to disclose and understand the features of modern society in the age of globalisation, representing the unlimited domination of the capitalist market economy. For Hayden White, this reality of modern societies is a dystopia realised. Its reality, culturally presented by historical thinking, "has turned out to be the nightmare from which we cannot awaken". History presents temporal change in such a way that modern societies in their current life-form represent a still-stand of change in the form of permanent dehumanisation, destroying any chance of overcoming it using the same time procedures that have led to it. I think one can apply the concept of "dialectics at a standstill" (Benjamin) to White's dystopian diagnosis of our time and the role that historical thinking plays in maintaining the permanence of its catastrophic features. Since reality is the catastrophe, the only way of overcoming it is utopian.

With this diagnosis of our time, Hayden White opens up a completely new perspective on utopian thinking. Since the nightmare of unlimited capitalism includes the consequences of traditional modern utopian thinking, a completely new form of utopia appears on the horizon of our present-day cultural orientation. In an impressive similarity to Walter Benjamin, White discloses a new utopian perspective of our lives: it is the paradise from which the angel of history has turned his face, so utopia does not come into view but nevertheless moves the mind of those who disclose the barbarism of our time. It makes them aware of the potentiality of overcoming this barbarism. Although White does not say very much about this moving force and its manifestation in present-day culture, his own radical analysis at least can only be understood as a part of this movement. The paradigm for the potential of awakening from the nightmare of modernity and escaping its horror is art. (Incidentally, this comes very close to the philosophy of history of Friedrich Schiller, for whom art was the only possibility for humanism in modern societies that were driven by human or even anti-human forces of 
unleashed needs in economy and unlimited rationality as a means of domination of nature as well as of the human world.)

Antonis Liakos's article on "Utopian and Historical Thinking: Interplays and Transferences" presents a comprehensive perspective within which both the case studies and the general concepts of a paradigmatic shift of utopian thinking at the turn into the twenty-first century can be discussed, mainly by referring our modern and post-modern developments to pre-modern ways of referring to historical experience, and to its transgression into utopian-like concepts of fulfilment. He presents a case study of the Book of Daniel and its importance in Western historical theory. In pre-modern times, eschatology can be seen as a form of utopia; it was an imagination of the future related to history in a very complicated way. Given the complicated nature of the interrelationship between all these concepts and principles, I cannot comment on the very complex relationship between history and eschatology, between the past and the future, and between historical experience and prophetic outlooks beyond it. However, this complexity leads to one essential finding: history and utopia are essentially mediated on the horizon of this pre-modern Christian theological concept. As Liakos notes, in the Book of Daniel "history was placed in the shell of eschatological thinking. It was impossible to think about the past without a framework comprising the future."

This mediation came to an end with the emergence of modern utopian thinking in the seventeenth century, when history and eschatology fell apart. The past became closed, and history fulfilled the function of "taming the consciousness of time", according to Liakos, who adds that, "the past was mastered, completely closed, and without promises yet to be fulfilled".

History has become useless, at least in respect to the inspiring forces of the human mind, making the person a factor in the changing of the pre-existing circumstances of practical life. In a fascinating historical overview, Liakos characterises the development of the relationship between history and utopia up to the present. A new synthesis of history and utopia occurred at the very moment when the eighteenth-century Enlightenment returned time back to the utopian dimension. Utopia became, in Liakos's words, euchronia. He follows this development up to the emergence of the social sciences on the threshold of the twentieth century, and shows that there was a permanent encounter between utopia and history. For instance, the concept of modernisation, which played an enormous role in historical interpretation, integrated utopian outlooks of the future with empirical views of the experience of the past.

Liakos distinguishes between three discourses in which history and utopia are merged. Firstly, the discourse in which utopia makes history meaningful, referring to Karl Mannheim in this context. Secondly, he refers to the turn of utopia to dystopia, where the absence of history is a nightmare, which contrasts with the other classical utopias. George Orwell is paradigmatic here. Thirdly, he discusses a discourse in which the past itself gives "new values for the future". Utopia is fed by a nostalgic relationship to the past. Utopia here has become a re-enactment of the possibilities of the past in juxtaposition to the present. E. P. Thompson is paradigmatic for this discourse. In the topical discussion about the relationship between history and utopia, Liakos emphasises the importance of history for a utopian outlook on the future: here history plays "the role of saving the past as a utopian background for the still unfulfilled". 
In his argumentation, Antoon de Baets goes against the grain of the other contributors in his article "A Successful Utopia: The Doctrine of Human Dignity". It thematises one basic cultural principle of modern societies, namely the concept of human dignity, from four different perspectives. Firstly, he undertakes a systematic analysis of its components, structure and role in constitutional law all over the world. It is worthwhile mentioning at this point that three-quarters of the 193 state constitutions currently in force refer to it. Secondly, he analyses the development of this principle mainly in Western history from an historical perspective. Thirdly, regarding the theme of this volume, he looks at utopian components in the concept of human dignity, before, finally, reflecting on the possibility of applying this concept to our historical relationship to the past with the intention of ascribing dignity to the people of the past by way of representing it historically.

De Baets's systematic analysis comes close to the present discussion about human rights, their universal validity and their role in organising political domination in social life on the principles of law. As regards the question of whether there is a utopian component in the concept of human dignity, he argues that while some common ground exists between dignity and utopia, there are other elements in the concept of human dignity that are essentially anti-utopian. One of the differences he emphasises seems to be most enlightening: utopia refers to perfection, whereas dignity is an issue of perfecting. He does not provide his own theory of human dignity but a very differentiated account of the current international discussion on it, and on the basis of this discussion, his impression is that the concept of human dignity is "confusing and controversial" and "partly utopian". Thus, we should leave it to the philosophers and lawyers to lead us out of this confusion and controversy, while we should follow de Baets's ideas about applying the concept of human dignity in our historical treatment of the past. Since dignity is a quality associated with the living, it is not easy to apply it to bygone generations. On the other hand, they were people and this should be systematically taken into account by historians. De Baets refers simultaneously to this difference and similarity by distinguishing between human and posthumous dignity, defining the latter as an issue of showing respect for the people of the past, which can be realised in the various forms of representing their lives and times historically.

How does the concept of human dignity relate to the question of the interrelationship between utopia and history? De Baets speaks of a "successful utopia" where there are ethical principles of human world interpretation and where there is cultural regulation of practical life which has a meta-empirical status, in which all human beings are ascribed values which very often have been neglected in real life. Nevertheless, in the long perspective of historical development this transcending quality has become an effective principle of organising human life at least in constitutions which tame the use of political power by limiting it through the application of the fundamental principles of law.

Ioanna Laliotou's article on "Timely Utopias: Notes on Utopian Thinking and Criticism in the Twentieth Century" provides an overview of different forms of utopian thinking in the previous and at the beginning of the present century. It starts by citing the well-known thesis that the year 1989 marked a definite end to utopian thinking. She clearly shows that after this declaration, utopian thinking not only continued but even experienced an impressive re-emergence. This renaissance is demonstrated by a set of examples representing different realms of culture: intellectual reflection as well as film, philosophy as well as popular culture, reflection on utopian thinking as well as utopia as presented in literature. Laliotou uses a rather wide concept of utopia, emphasising potentiality rather than real- 
ity. With this fundamental distinction, she is able to describe a variety of representative counterfactual potentialities of phenomena, events, human life-forms, perspectives of the future and imagined alternatives to empirical experience.

Confronted with this variety of different potentialities, historical thinking takes a different approach to the past. The past itself is no longer presented as a more or less continuous line of development into the present, but as a realm of experiences which disrupts this line and gives the past a distinctive, different quality to the past. In this form, it appears as a potential in itself, the irritating feature that the present-day life-form is not a necessary consequence of what has happened in the past, but that it could have happened differently. Confronted with the reality of the current life-form, the historically presented past earns a kind of a utopian quality. The re-emergence of utopian thinking has opened up chances for history to change its traditional ('realistic') mode of making sense of the past.

Yannis Smarnakis's article, "A Contribution to the Archaeology of Modern Utopian Thought: History and Utopia in Plethon's Oeuvre", deals with an interesting example of an early modern thinker who presented utopian ideas as well as historiographical texts. In contrast to Thomas More, the Byzantine Plethon does not present a clear contradiction between history and utopia. Although his utopian concept of an ideal state is a 'construction' as opposed to reality, the normative character of this construction tackles the exemplary mode of Plethon's historiography, which emphasises the moral rules of human behaviour. Utopia can be understood as transcending this morality derived from historical experience beyond its realm. In this case, utopia and history coexist without tension or mutual provocation. In this respect, Plethon represents a rather traditional way of placing the idea of an ideal state and the historiographical representation of a past side by side. Thomas More's Utopia marks a decisive step in giving the description of an ideal state a counterfactual shape, thus opening up a new dimension of thematising social reality by describing its counter-image.

Syrago Tsiara's article "Utopia and Reality in the Art of the October Revolution" leads us to the end of this clear contrast between reality and its transgression into utopia. The Russian Revolution presents the most radical example in modern Western history of a durable attempt to create utopia by changing the pre-given circumstances and conditions of human life. As essential components of revolution, philosophy, political ideology and, in particular, art were committed to breathing reality into the hitherto utopian perspective of liberating humankind from all obstacles to its humanity. As regards this commitment, utopia as utopia has come to a definite end, in so far as it is characterised by the hope that the counterfactual images of a better world can initiate and inspire practical changes in the human world which would bring it closer to the ideal feature presented by utopia. It is interesting to learn that these trans-utopian attempts made use of traditional Christian (Orthodox) images and semantics of transcendence. However, this is only one element in making utopias realistic through revolutionary practice; other elements include new and avant-garde forms of fine art, such as futurism and constructivism.

Tsiara is not so much interested in reflecting on the conceptual framework of her interpretation, but more in the empirical complexity and diversity of artistic means in propagating revolutionary practice as a new instrumentalisation of utopian elements in future political projections propagating revolutionary practice. In the aftermath of Communist rule, the consequences of this practice are evident: 
its obvious inhumanity cannot be sufficiently explained without referring precisely to those intellectual and artistic movements which inspired the Revolution in the hope that it could bring about a reality which hitherto could only be imagined in contrast to reality. Hayden White's contribution shows that art is loosing its inbuilt utopian quality in the context of modernity by seeking to abandon its aesthetic separation from politics and to become an element of political liberation. After the end of the communist experiment to give utopian thinking a realistic form, art has lost its specific potential. Its potential was the opening up a dimension of possibilities within which human suffering could articulate itself and find an expression of its end; the potential of transgressing the realm of all the limiting conditions on human life in favour of strengthening the human abilities to overcome them and, in doing so, to manifest the liberating forces of the human mind.

It is impossible to synthesise the outcomes of all the different contributions into a coherent idea on the interrelationship between history and utopia. In surveying all the articles, one can come to a conclusion which gives our question a specifically historical meaning. Most contributions agree that at the beginning of the twenty-first century, the hitherto dominating interrelationship between utopian and historical thinking has come to its end. The proclaimed end of utopia holds true as regards its modern conception, and it was wrong in respect of the exuberant power of the human mind: yet, an essentially new way of realising this exuberance in the form of utopia is emerging and art is paradigmatic for it. What does this mean for history? I would like to pick up on Hayden White's very radical interpretation of historical thinking in its modern form as representing the reality principle in the human relationship to the world, and state that this traditional historical thinking, with its anti-utopian logic by its strict reference to experience, has perished. But this does not mean that historical thinking has come to an end. On the contrary; to the same degree in which utopian thinking is being paradigmatically reshaped today, history can be reshaped as well. It can be inspired by the utopian quality of virtuality in the new media; it can be challenged by the paradigmatic function of art in transgressing the burden of reality. It can contribute in the materialisation of these new utopian forces of the human mind in its very specific relationship to the experience of the past, not by negating them, but by using them in order to present the past as something open, unsettled, and as a promise and a challenge: in short, as a realm of experience which we need in order to find our way as humans in the pre-given circumstances of a world suffering under their inhumane structures, propelled by the exuberance of our minds towards our visions of humanity. In this movement, utopia and history synthesise. We ourselves live this synthesis.

Jörn Rüsen

\section{FOOTNOTES}

1 Leopold von Ranke, Geschichten der romanischen und germanischen Völker von 1494-1514, Sämtliche Werke, vol. 33, Leipzig: Duncker und Humblot, 1855, p. viii.

2 Michael Winter, Ende eines Traums. Blick zurück auf das utopische Zeitalter Europas, Stuttgart: Metzler, 1993; Richard Saage, Das Ende der politischen Utopie, Frankfurt am Main: Suhrkamp, 1990; Joachim Fest, Der zerstörte Traum. Vom Ende des utopischen Zeitalters, Berlin: Siedler, 1991.

3 Most of them were presented initially at the "History and Utopia" panel, itself part of the in the major "History and Myth" theme, at the 20th International Congress of Historical Sciences, Sydney, July 2005. 